\title{
Moraxella lincolnii sp. nov., Isolated from the Human Respiratory Tract, and Reevaluation of the Taxonomic Position of Moraxella osloensis
}

\author{
P. VANDAMME,${ }^{1,2 *}$ M. GILLIS, ${ }^{1}$ M. VANCANNEYT, ${ }^{1}$ B. HOSTE, ${ }^{1}$ K. KERSTERS, ${ }^{1}$ AND E. FALSEN ${ }^{3}$ \\ Laboratorium voor Microbiologie, University of Ghent, $K$. L. Ledeganckstraat 35, B-9000 Ghent, ${ }^{1}$ and \\ Department of Microbiology, University Hospital, Antwerp, ${ }^{2}$ Belgium, and Culture Collection, \\ Department of Clinical Bacteriology, University of Göteborg, \\ S-413 46 Göteborg, Sweden ${ }^{3}$
}

\begin{abstract}
A polyphasic taxonomic study was performed to determine the relationships of 10 Moraxella-like strains isolated mainly from the human respiratory tract in Sweden. Two of the strains formed a separate subgroup on the basis of both their protein contents and their fatty acid contents. However, the overall protein and fatty acid profiles revealed that all 10 strains were highly related. Representative strains of the two subgroups exhibited high DNA binding values $(\mathbf{9 8 \%})$ with each other and had an identical DNA base ratio (44 mol\% G+C). DNA-rRNA hybridizations revealed that this taxon can be included in the genus Moraxella, which is only distantly related to phenotypically similar genera, such as the genera Neisseria and Kingella. The results of an extensive phenotypic analysis indicated that the general biochemical profile of the 10 strains conforms with the description of the genus Moraxella given in Bergey's Manual of Systematic Bacteriology. We therefore consider these organisms members of a new Moraxella species, for which the name Moraxella lincolnii is proposed. Furthermore, we also conclude that Moraxella osloensis belongs, genotypically as well as phenotypically, to the genus Moraxella.
\end{abstract}

Between 1980 and 1989, 10 Moraxella-like strains were isolated in Sweden, mainly from the human respiratory tract. In October 1980, immunotyping (Ouchterlony immunodiffusion and immunoelectrophoresis) was performed on the first three isolates, and the results revealed that the strains represented a distinct taxon which was provisionally named "Moraxella lincolnii." Subsequent isolates were rapidly identified. In the present study we used a polyphasic approach to determine the phenotypic and genotypic affiliation of these organisms. We found that the 10 strains constitute a new species belonging to the genus Moraxella, and we propose the name Moraxella lincolnii sp. nov. This name is used below. In view of the new data and recently published results (9), we also reevaluated the taxonomic position of Moraxella osloensis as the arguments used by Rossau et al. to remove this species from the genus Moraxella (18) were not conclusive.

\section{MATERIALS AND METHODS}

Bacterial strains and growth conditions. All of the strains used are listed in Table 1 . We obtained weak growth of $M$. lincolnii strains on several blood agar bases, including 5\% (vol/vol) horse blood in Mueller-Hinton agar (catalog no. CM337; Oxoid, Ltd., Basingstoke, United Kingdom), nutrient agar no. 2 (catalog no. CM67; Oxoid), Columbia agar (catalog no. CM331; Oxoid), and heart infusion agar (catalog no. 0038-01-5; Difco Laboratories, Detroit, Mich.). Growth was not markedly enhanced on chocolate agar plates. The best growth results were obtained on a medium routinely used in our department for the cultivation of fastidious Campylobacter strains. This medium contains (per liter) $10 \mathrm{~g}$

\footnotetext{
* Corresponding author.
}

of special peptone (catalog no. L72; Oxoid), $5 \mathrm{~g}$ of Lab Lemco powder (catalog no. L29; Oxoid), $5 \mathrm{~g}$ of yeast extract (catalog no. L21; Oxoid), $5 \mathrm{~g}$ of sodium chloride, $2 \mathrm{~g}$ of sodium succinate hexahydrate, $2 \mathrm{~g}$ of sodium L-glutamate monohydrate, $1 \mathrm{~g}$ of magnesium chloride hexahydrate, and $15 \mathrm{~g}$ of agar no. 3 (catalog no. L13; Oxoid); the final pH is 7.0 . This medium was supplemented with $5 \%$ (vol/vol) horse blood and is referred to below as standard medium. Optimal growth results were obtained at $28^{\circ} \mathrm{C}$ in a microaerobic atmosphere containing $5 \% \mathrm{O}_{2}, 10 \% \mathrm{CO}_{2}$, and $85 \% \mathrm{~N}_{2} . M$. osloensis strains and reference strains belonging to other Moraxella species were cultivated aerobically at $28^{\circ} \mathrm{C}$ on heart infusion agar (Difco).

Phenotypic tests. Phenotypic tests were performed on all $M$. lincolnii strains and on Moraxella reference strains. The morphology of cells was evaluated by Gram staining. Motility was observed in young cultures by examining wet mounts in broth by phase-contrast microscopy. The following tests were performed as described previously (5): presence of oxidase, catalase, $\beta$-galactosidase, DNase, and urease; production of indole; reduction of nitrate and nitrite; denitrification; growth under anaerobic conditions; growth on Drigalski agar; growth at different temperatures; growth in the presence of different concentrations of $\mathrm{NaCl}$; oxidation or fermentation of D-glucose; liquefaction of gelatin; proteolysis on Löfler slants; hydrolysis of Tween 80 ; tolerance of penicillin (10- $\mu$ g discs); hemolysis and odor on horse blood agar; and formation of pigment on nutrient agar. Acid production from D-glucose, maltose, D-fructose, and sucrose was evaluated in a medium containing $15 \mathrm{~g}$ of Proteose Peptone no. 3 (catalog no. 0122; Difco), $4.5 \mathrm{~g}$ of NaCl, $3.0 \mathrm{~g}$ of $\mathrm{Na}_{2} \mathrm{HPO}_{4} \cdot 2 \mathrm{H}_{2} \mathrm{O}, 1.5 \mathrm{~g}$ of sodium alginate, and $17 \mathrm{~g}$ of Bacto Agar (catalog no. 0140; Difco) in 1,000 ml of placenta extract (the $\mathrm{pH}$ was adjusted to 7.7). This basal medium was supplemented with $2.5 \mathrm{ml}$ of phenol red $(0.5 \%$ solution $), 5 \mathrm{ml}$ of hemin ( $0.2 \%$ solution), $90 \mathrm{ml}$ of ascitic fluid, and $10 \mathrm{ml}$ of 
TABLE 1. Strains used

\begin{tabular}{|c|c|c|c|}
\hline Taxon & Strain $^{a}$ & $\begin{array}{l}\text { Received } \\
\text { from }{ }^{a}:\end{array}$ & Source, if known \\
\hline M. lincolnii & CCUG $9405^{\mathrm{T}}\left(=\right.$ LMG $\left.5127^{\mathrm{T}}\right)$ & Lincoln & $\begin{array}{l}\text { Human nasopharynx, 6-mo-old female with fever (1980, } \\
\text { Sweden) }\end{array}$ \\
\hline M. lincolnii & CCUG 9406 (= LMG 10487) & Lincoln & $\begin{array}{l}\text { Human throat, } 1.5 \text {-yr-old male, respiratory tract } \\
\text { infection }(1980, \text { Sweden })\end{array}$ \\
\hline M. lincolnii & CCUG 9511 (= LMG 10488) & Lange & Human nasopharynx, 1.5-yr-old female (1980, Sweden) \\
\hline M. lincolnii & CCUG 11973 (= LMG 10489) & Dennford & $\begin{array}{l}\text { Human nasopharynx, 2-yr-old child, whooping cough } \\
\text { specimen (1982, Sweden) }\end{array}$ \\
\hline M. lincolnii & CCUG 17467 (= LMG 10490) & PHL & Human nasopharynx, 21-yr-old female (1985, Sweden) \\
\hline M. lincolnii & CCUG 18789 (= LMG 10491) & Dennford & Human eye, 5-mo-old male (1986, Sweden) \\
\hline M. lincolnii & CCUG 20072 (= LMG 10492) & Brönnestam & Human respiratory tract, 11 -mo-old male (1987, Sweden) \\
\hline M. lincolnii & CCUG 20073 (= LMG 10493) & Brönnestam & Human nasopharynx, 1-yr-old male (1987, Sweden) \\
\hline M. lincolnii & CCUG 21674 (= LMG 10494) & PHL & Human nasopharynx, 6.5-yr-old female (1987, Sweden) \\
\hline M. lincolnii & CCUG 24769 (= LMG 10495) & PHL & Human blood, bursitis of the left knee (1989, Sweden) \\
\hline M. osloensis & LMG 987 (= ATCC 10973) & TRS & \\
\hline M. osloensis & $\begin{array}{l}\text { LMG } 1043(=\text { ATCC } 19961= \\
\text { NCTC 10756) }\end{array}$ & TRS & Human urine (1951, Norway) \\
\hline M. osloensis & $\begin{array}{l}\text { LMG } 1044 \text { (= ATCC } 19963= \\
\text { NCTC 10749) }\end{array}$ & TRS & Human nose (1951, Norway) \\
\hline M. osloensis & CCUG 63 (= LMG 6916) & Lincoln & $\begin{array}{l}\text { Human urine, 10-yr-old girl, suspected pyelonephritis (1968, } \\
\text { Sweden) }\end{array}$ \\
\hline M. osloensis & $\begin{array}{l}\text { CCUG } 350^{\mathrm{T}}\left(=\text { LMG } 5131^{\mathrm{T}}=\right. \\
\left.\text { ATCC } 19976^{\mathrm{T}}\right)\end{array}$ & Bøvre & Human cerebrospinal fluid \\
\hline M. osloensis & CCUG 11977 (= LMG 6917) & PHL & $\begin{array}{l}\text { Human blood, 82-yr-old male with pneumonia (1982, } \\
\text { Sweden) }\end{array}$ \\
\hline M. osloensis & CCUG 13305 (= LMG 6918) & PHL & $\begin{array}{l}\text { Human abdomen, 15-yr-old female, pus from } \\
\text { appendix (1983, Sweden) }\end{array}$ \\
\hline M. osloensis & CCUG 13369 (=LMG 6919) & PHL & Human blood, 8-yr-old male (1983, Sweden) \\
\hline M. osloensis & CCUG 13705 (= LMG 6920) & PHL & $\begin{array}{l}\text { Human cerebrospinal fluid, 24-yr-old female, } \\
\text { meningitis (1983, Sweden) }\end{array}$ \\
\hline M. atlantae & $\begin{array}{l}\text { CCUG } 6415^{\mathrm{T}}\left(=\text { LMG } 5133^{\mathrm{T}}=\right. \\
{\left.\text { ATCC } 29525^{\mathrm{T}}\right)}^{\text {LTC }}\end{array}$ & Bøvre & Human blood (United States) \\
\hline M. bovis & $\begin{array}{l}\text { CCUG } 2133^{\mathrm{T}}\left(=\text { LMG } 986^{\mathrm{T}}=\right. \\
\left.\quad \text { ATCC } 10900^{\mathrm{T}}\right)\end{array}$ & Bøvre & Cattle, pinkeye \\
\hline M. canis & CCUG $8415 A^{\mathrm{T}}\left(=\right.$ LMG $\left.11194^{\mathrm{T}}\right)$ & PHL & Human wound, 29-yr-old woman, dog bite (1979, Sweden) \\
\hline M. catarrhalis & $\begin{array}{l}\text { CCUG } 353^{\mathrm{T}}\left(=\text { LMG } 11192^{\mathrm{T}}=\right. \\
\left.\quad \text { ATCC } 25238^{\mathrm{T}}\right)\end{array}$ & Bøvre & \\
\hline M. caviae & $\begin{array}{l}\text { CCUG } 355^{\mathrm{T}}\left(=\text { LMG } 5129^{\mathrm{T}}=\right. \\
\text { ATCC } 14659^{\mathrm{T}}=\text { CCUG } \\
\left.2132^{\mathrm{T}}\right)\end{array}$ & Bøvre & Pharynx, guinea pig (United States) \\
\hline M. cuniculi & $\begin{array}{l}\text { CCUG } 2154^{\mathrm{T}}\left(=\text { LMG } 8382^{\mathrm{T}}=\right. \\
\left.\text { ATCC } 14688^{\mathrm{T}}\right)\end{array}$ & Berger & Rabbit oral mucosa \\
\hline M. lacunata & $\begin{array}{l}\text { CCUG } 4441^{\mathrm{T}}\left(=\text { LMG } 5301^{\mathrm{T}}=\right. \\
\text { CIP A182 })\end{array}$ & CIP & Subacute conjunctivitis \\
\hline M. lacunata & $\begin{array}{l}\text { LMG } 1009(=\text { ATCC } 17952= \\
\text { CCUG } 4862=\text { NCTC } 7911)\end{array}$ & TRS & \\
\hline $\begin{array}{l}\text { M. nonlique- } \\
\text { faciens }\end{array}$ & $\begin{array}{l}\text { CCUG } 348^{\mathrm{T}}\left(=\text { ATCC } 19975^{\mathrm{T}}=\right. \\
\left.\text { NCTC } 10464^{\mathrm{T}}\right)\end{array}$ & Bøvre & Nose swab \\
\hline $\begin{array}{l}\text { M. nonlique- } \\
\text { faciens }\end{array}$ & LMG 1011 (= ATCC 17954) & TRS & Human throat swab (1950, Canada) \\
\hline M. ovis & $\begin{array}{l}\text { CCUG } 354^{\mathrm{T}}\left(=\text { LMG } 8381^{\mathrm{T}}=\right. \\
\left.\text { ATCC } 33078^{\mathrm{T}}\right)\end{array}$ & Bøvre & Ovine eye, conjunctivitis \\
\hline
\end{tabular}

${ }^{a}$ ATCC, American Type Culture Collection, Rockville, Md.; Berger, U. Berger, Heidelberg, Germany; Brönnestam, R. Brönnestam, Skovde, Sweden; Bøvre, K. Bøvre, Oslo, Norway; CCUG, Culture Collection, University of Göteborg, Göteborg, Sweden; CIP, Collection de l'Institut Pasteur, Paris, France; Dennford, J. Dennford, Borås, Sweden; Lange, S. Lange, Göteborg, Sweden; LMG, Culture Collection of the Laboratorium voor Microbiologie, University of Ghent, Ghent, Belgium; Lincoln, K. Lincoln, Göteborg, Sweden; NCTC, National Collection of Type Cultures, London, United Kingdom; PHL, Public Health Laboratory Service, Göteborg, Sweden; TRS, Torry Research Station, Aberdeen, Scotland.

a $30 \%$ carbohydrate solution. API ZYM tests were performed according to the recommendations of the manufacturer (API bioMérieux, La Balme-les-Grottes, MontalieuVercieu, France).

The following enzymes belonging to a noncommercial API gallery were found to be useful for differentiation of Moraxella species: $\gamma$-glutamyl arylamidase, glycine aryl- amidase, lysine arylamidase, proline arylamidase, $\alpha$-glutamyl- $\alpha$-glutamic acid arylamidase, glycyl-phenylalanine arylamidase, prolyl-arginine arylamidase, seryl-methionine arylamidase, and alanyl-phenylalanyl-prolyl-alanine arylamidase.

Gas chromatographic analysis of fatty acid methyl esters. Fatty acid compositions were determined after cultivation of 


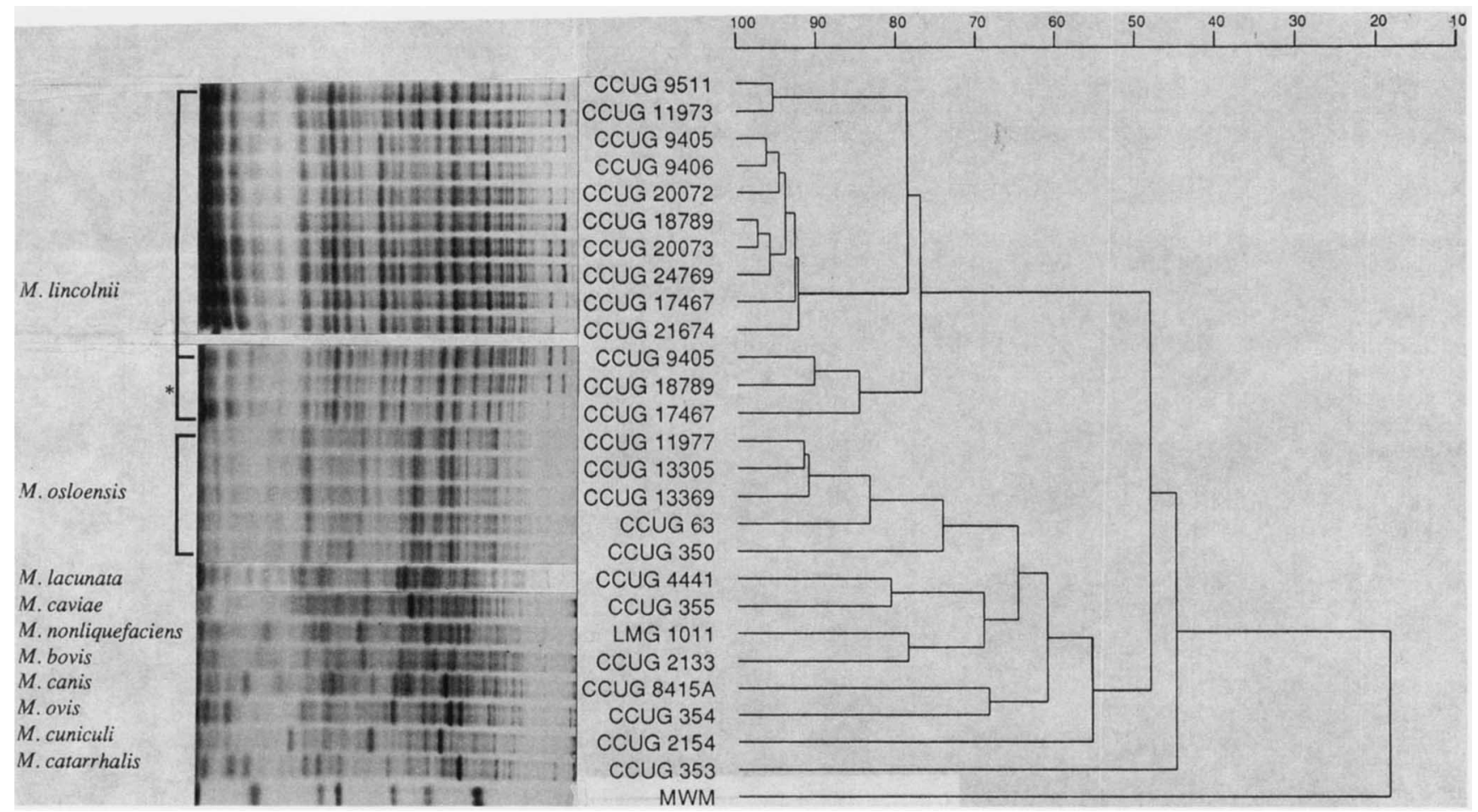

FIG. 1. Electrophoretic protein profiles and corresponding dendrogram derived from unweighted pair group average linkage of correlation coefficients for the protein patterns of all of the strains studied. The following molecular weight markers (track MWM) were used (from left to right): lysozyme (molecular weight, 14,500$)$, trypsin inhibitor $(20,100)$, trypsinogen $(24,000)$, carbonic anhydrase $(29,000)$, glyceraldehyde3 -phosphate dehydrogenase $(36,000)$, egg albumin $(45,000)$, and bovine albumin $(66,000)$. The $M$. lincolnii strains marked with an asterisk were cultivated under the conditions used for Moraxella reference strains.

cells for $24 \mathrm{~h}$ on Trypticase soy agar (catalog no. 11768; BBL Microbiology Systems, Cockeysville, Md.) at $28^{\circ} \mathrm{C}$. All $M$. lincolnii strains were incubated microaerobically. $M$. osloensis strains, as well as two representative $M$. lincolnii strains (strains CCUG $9405^{\mathrm{T}}$ [ $\mathrm{T}=$ type strain] and CCUG 18789), were incubated aerobically.

A loopful of well-grown cells was harvested, and fatty acid methyl esters were prepared, separated, and identified as described previously (22).

PAGE of whole-cell proteins. All $M$. lincolnii strains were cultivated under microaerobic conditions on standard medium. $M$. osloensis strains, all Moraxella reference strains, and three representative $M$. lincolnii strains (CCUG $9405^{\mathrm{T}}$, CCUG 17467, and CCUG 18789) were grown for $48 \mathrm{~h}$ on heart infusion agar (Difco) at $28^{\circ} \mathrm{C}$. Whole-cell protein extracts were prepared, and sodium dodecyl sulfate-polyacrylamide gel electrophoresis (PAGE) was performed as described previously (13).

Numerical analysis of the protein gel electropherograms. A densitometric analysis, normalization and interpolation of the protein profiles, and a numerical analysis were performed by using the GelCompar software package (Applied Maths, Kortrijk, Belgium). The profiles were recorded and stored on a PC-AT computer. The similarity between pairs of traces was expressed by the Pearson product moment correlation coefficient, converted for convenience to a percentage. The stacking gel-separation gel interface and the protein bands with a molecular weight below 22,000 (Fig. 1) were not used in the numerical analysis.

Preparation of high-molecular-weight DNAs. High-molecular-weight native DNAs of $M$. lincolnii strains were prepared from 1- to 2-g portions of wet cells as described previously (22). DNAs from Moraxella reference strains and $M$. osloensis were available from previous studies $(9,18)$.

DNA-DNA hybridization experiments. The degree of DNADNA binding, expressed as a percentage, was determined spectrophotometrically by the initial renaturation rate method (4). Each value given below is the average of values from at least two hybridization experiments. DNA-DNA binding values of $30 \%$ and less indicate no significant DNA homology. The total DNA concentration was about 57 $\mu \mathrm{g} / \mathrm{ml}$, and the optimal renaturation temperature in $1 \times \mathrm{SSC}$ $\left(0.15 \mathrm{M} \mathrm{NaCl}\right.$ plus $0.015 \mathrm{M}$ sodium citrate) was $64.9^{\circ} \mathrm{C}$.

DNA base compositions. The mean guanine-plus-cytosine $(\mathrm{G}+\mathrm{C})$ contents were determined by the thermal denaturation method and were calculated by using the equation of Marmur and Doty (14), as modified by De Ley (3).

DNA-rRNA hybridization experiments. In vivo radioactively labelled rRNA from Moraxella lacunata LMG 1009 was available in our research group. Fixation of singlestranded DNA on membrane filters, chemical determination of the amount of DNA on a filter, saturation hybridization, RNase treatment, and thermostability measurements of hybrids were performed as described by Van Landschoot and De Ley (23). Each DNA-rRNA hybrid was characterized by its $T_{m(e)}$ (melting temperature of elution), the temperature at which $50 \%$ of the hybrid was denatured. The higher the $T_{m(e)}$ of a heterologous hybrid, the closer it was related to the reference strain (homologous hybrid).

Immunotyping analysis. Preparation of antigens, immunization, and immunodiffusion were performed by the method of Falsen (6), as described previously (20). Antisera were 
prepared against $M$. lincolnii CCUG $9405^{\mathrm{T}}$ and CCUG 9511 and against reference strains of $M$. osloensis, $M$. lacunata, Moraxella nonliquefaciens, Moraxella bovis, Moraxella ovis, Moraxella catarrhalis, Moraxella caviae, and Moraxella atlantae. Antigens were prepared from all $M$. lincolnii strains and Moraxella reference strains.

\section{RESULTS}

Phenotypic analysis. The following features were present in all of the strains tested: oxidase activity, susceptibility to penicillin $\left(10-\mu \mathrm{g}\right.$ discs), growth at $37^{\circ} \mathrm{C}$, growth in a $\mathrm{CO}_{2}-$ enriched atmosphere, growth in the absence of $\mathrm{NaCl}$, ester lipase $\mathrm{C}_{8}$ activity, and leucine arylamidase activity. The following features were absent in all strains: motility, pigment production, odor production, anaerobic growth, oxidation or fermentation of glucose, denitrification, production of indole, urease activity, $\beta$-galactosidase activity, growth in the presence of 7.5 and $10 \% \mathrm{NaCl}$, production of acid from D-glucose, maltose, D-fructose, and sucrose, and lipase $\left(\mathrm{C}_{14}\right)$, valine arylamidase, cysteine arylamidase, trypsin, chymotrypsin, $\alpha$-galactosidase, $\beta$-glucuronidase, $\alpha$-glucosidase, $\beta$-glucosidase, $N$-acetyl- $\beta$-glucosaminidase, $\alpha$-mannosidase, and $\alpha$-fucosidase activities. Tests that yielded variable results are shown in Table 2.

The type strains of all other Moraxella species were included as reference strains. Sometimes, the reactions of these type strains differed in some tests from the reactions of other strains belonging to the same species (7). For these tests, the general reaction pattern of the species is given in a footnote to Table 2. A number of discrepancies with our previous test results (9) were noted (M. ovis and Moraxella cuniculi strains produced DNase and $M$. caviae reduced nitrate in previous tests, whereas the opposite reactions were recorded in this study).

Fatty acid methyl ester composition. The fatty acid methyl ester compositions of all $M$. lincolnii and $M$. osloensis strains studied are shown in Table 3. Fatty acids which accounted for less than $1 \%$ of the total fatty acids in all of the strains studied are not given; therefore, the percentages in Table 3 do not always add up to $100 \%$. M. lincolnii strains have $10: 0,12: 030 \mathrm{H}, 16: 1 \mathrm{cis}-9,16: 0,18: 1 \mathrm{cis}-9$, and 18:0 as their major components. $M$. osloensis strains have 10:0, 16:1 cis-9, and 18:1 cis-9 as their major components. The unidentified fatty acid methyl ester with an equivalent chain length of 15.490 was considered 14:0 3OH (15).

The fatty acid compositions of two $M$. lincolnii strains were considerably influenced by the composition of the gas atmosphere. The differences were most apparent in the ratio of $16: 1 \mathrm{cis}-9$ to $18: 1 \mathrm{cis}-9$, which was approximately 0.5 under microaerobic conditions and 2.0 under aerobic conditions.

Two M. lincolnii strains (CCUG 9511 and CCUG 11973) do not contain 12:0, a fatty acid which is present at an average level of $3.7 \pm 0.7 \%$ in all other $M$. lincolnii strains. Below, these two strains are referred to as subgroup II strains, while subgroup $I$ is used for the remaining eight strains, including the type strain.

The fatty acid compositions of $\boldsymbol{M}$. osloensis strains are more heterogeneous than those of $M$. lincolnii strains, although so far no subgroups have been delineated. The general fatty acid profile of $M$. osloensis is similar to the profiles reported by Jantzen et al. (10) and Sugimoto et al. (19).

PAGE of whole-cell proteins. Duplicate protein extracts of several strains were prepared to check the reproducibility of the growth conditions and the preparation of the extracts. The level of correlation between duplicate protein patterns was more than $95 \%$.

Within $M$. lincolnii, two protein electrophoretic subgroups were found; the subgroup II strains (CCUG 9511 and CCUG 11973 ) have a profile which is considerably different from the profile of the other strains in the 34,000- to 45,000-molecularweight region (Fig. 1). In the dendrogram obtained after numerical analysis of the protein patterns, we found a level of correlation of $79 \%$ between the two subgroups (Fig. 1). To allow a comparison of the protein profiles of the $M$. lincolnii strains with the protein profiles of other Moraxella species, we also cultivated three $M$. lincolnii strains under the conditions used for Moraxella reference strains (Fig. 1, asterisk). The protein patterns of the Moraxella strains cultivated under different conditions differ mainly in the density of some protein bands (Fig. 1). These patterns cluster together with a level of correlation of $77 \%$ (Fig. 1).

All $M$. osloensis strains group above a level of correlation of $74 \%$. As Fig. 1 shows, the overall protein profiles of the $M$. osloensis strains are rather heterogeneous, although no subgroups can be delineated. The protein profiles of the other Moraxella reference strains are clearly different from the profiles of $M$. lincolnii strains and exhibit low correlation coefficients in comparisons with $M$. lincolnii and $M$. osloensis strains (less than 48 and $65 \%$, respectively).

DNA-rRNA hybridization results. Representative strains belonging to subgroups I and II (CCUG 24769 and CCUG 9511, respectively) were chosen to perform DNA-rRNA hybridizations. We obtained $T_{m(e)}$ values of $74.4^{\circ} \mathrm{C}$ (CCUG 9511) and $74.8^{\circ} \mathrm{C}$ (CCUG 24769) with $M$. lacunata LMG 1009 rRNA. These values are quite low because of the gradual decomposition of the ${ }^{3} \mathrm{H}$-labelled rRNA during storage (9) and are comparable to the slightly higher values found previously (18) for $M$. osloensis.

DNA-DNA hybridization results. Representative strains belonging to subgroups I and II (CCUG $9405^{\mathrm{T}}$ and CCUG 9511, respectively) were chosen to perform DNA-DNA hybridizations. These strains exhibited a high DNA-DNA binding value (98\%) with each other, but the DNA-DNA binding values with reference strains of other Moraxella species, including $M$. osloensis, were not significant (less than $30 \%$ ) (data not shown).

DNA base composition. The DNA base ratio of $M$. lincolnii CCUG 9511 and CCUG 24769 is $44 \mathrm{~mol} \% \mathrm{G}+\mathrm{C}$.

Immunotyping. All $M$. lincolnii strains exhibited high precipitation values with antisera prepared against the two $M$. lincolnii strains, while no significant precipitation values were recorded with antiserum prepared against any of the Moraxella reference strains (data not shown). Antigens from Moraxella reference strains did not cross-react with antiserum against $M$. lincolnii strains (data not shown).

\section{DISCUSSION}

The strains that we consider to be members of a new Moraxella species were obtained from diverse sources (Table 1). They were provisionally assigned to the genus $M o$ raxella on the basis of their Gram reaction, cellular morphology, absence of motility, and reactions in a restricted set of biochemical tests. Their assignment to the family the $\mathrm{Mo}$ raxellaceae was confirmed by DNA-rRNA hybridization data, which showed that these organisms are situated at the base of the $M$. lacunata rRNA homology group (18), which is phylogenetically far removed from phenotypically similar genera, such as the genera Neisseria and Kingella $(9,17,18)$. 


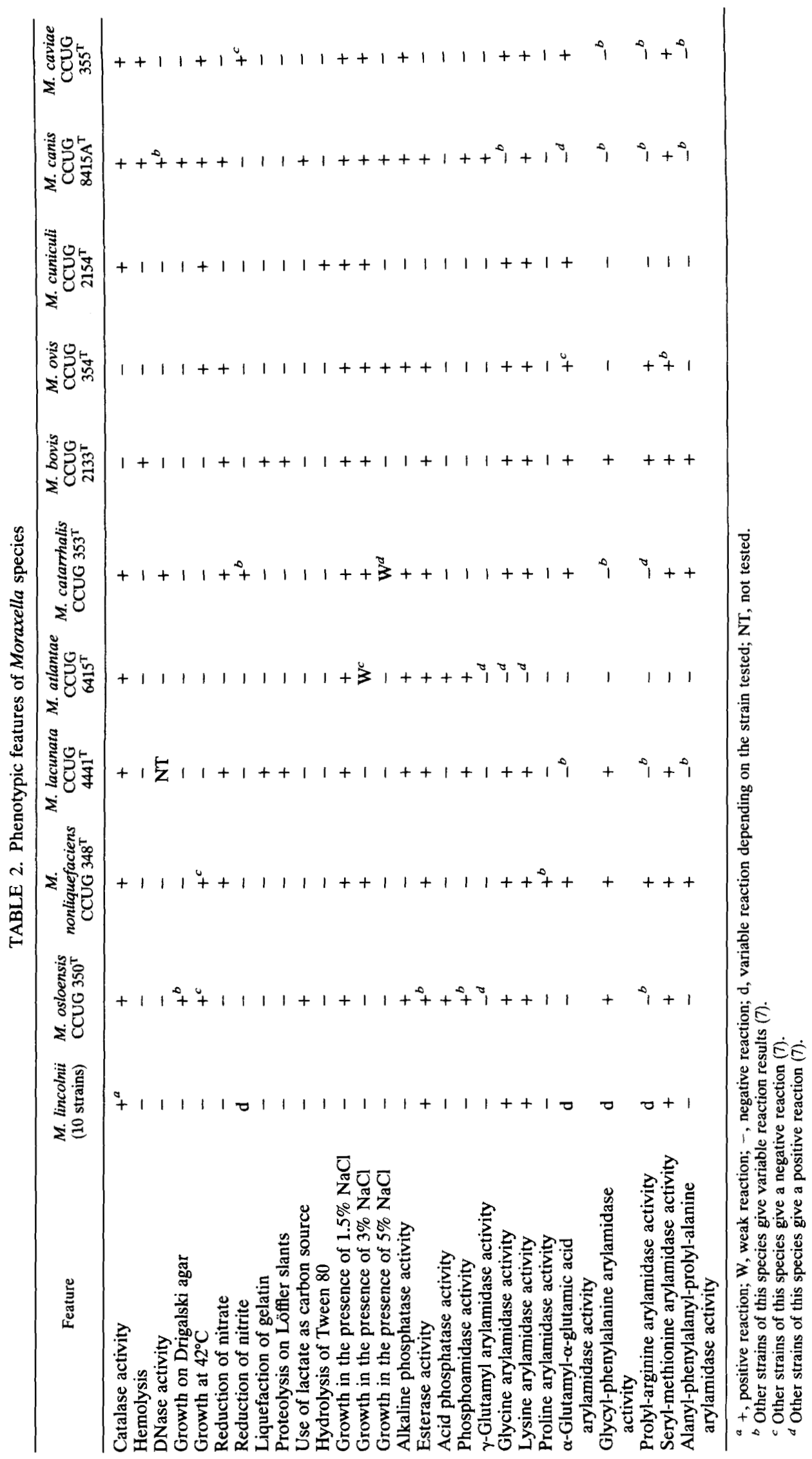


TABLE 3. Average fatty acid compositions of Moraxella strains

\begin{tabular}{|c|c|c|c|c|c|c|c|c|c|}
\hline \multirow{2}{*}{ Strain } & \multicolumn{9}{|c|}{$\%$ of: } \\
\hline & 10:0 & 12:0 & $12: 03 \mathrm{OH}$ & $14: 03 \mathrm{OH}$ & $16: 1 c i s-9$ & $16: 0$ & $17: 1 \mathrm{~B}^{\alpha}$ & $18: 1$ cis -9 & 18:0 \\
\hline \multicolumn{10}{|c|}{ M. lincolnii: aerobic conditions } \\
\hline CCUG $9405^{\mathrm{T}}$ & 9.0 & 5.5 & 9.5 & $-^{b}$ & 43.2 & 9.2 & - & 23.7 & \\
\hline CCUG 18789 & 7.8 & 4.9 & 7.9 & - & 47.8 & 9.8 & - & 21.8 & - \\
\hline \multicolumn{10}{|c|}{ M. lincolnii: microaerobic conditions } \\
\hline CCUG $9405^{T}$ & 6.4 & 3.8 & 6.9 & - & 24.0 & 10.8 & - & 44.8 & 3.4 \\
\hline CCUG 9406 & 5.1 & 3.2 & 5.1 & - & 24.2 & 12.0 & - & 47.1 & 3.4 \\
\hline CCUG 9511 & 6.1 & - & 9.3 & - & 23.7 & 11.3 & - & 46.0 & 3.7 \\
\hline CCUG 11973 & 4.5 & - & 6.5 & - & 23.4 & 13.1 & - & 48.9 & 3.7 \\
\hline CCUG 17467 & 6.3 & 3.7 & 6.3 & - & 25.0 & 9.6 & - & 45.8 & 3.3 \\
\hline CCUG 18789 & 6.2 & 4.0 & 6.4 & - & 20.0 & 10.3 & - & 48.6 & 4.7 \\
\hline CCUG 20072 & 8.7 & 5.4 & 8.9 & - & 26.7 & 9.3 & - & 37.7 & 3.1 \\
\hline CCUG 20073 & 4.9 & 3.3 & 4.7 & - & 18.9 & 10.3 & - & 53.0 & 5.0 \\
\hline CCUG 21674 & 5.1 & 3.4 & 5.1 & - & 15.5 & 10.3 & - & 53.8 & 5.7 \\
\hline CCUG 24769 & 4.7 & 3.0 & 4.6 & - & 21.3 & 12.0 & 1.0 & 48.2 & 4.6 \\
\hline \multicolumn{10}{|l|}{ M. osloensis } \\
\hline LMG 987 & - & - & 3.1 & 1.8 & 19.4 & 8.0 & - & 61.5 & 6.2 \\
\hline LMG 1043 & 7.4 & - & 4.0 & 1.7 & 19.3 & 3.4 & 2.2 & 59.7 & 2.4 \\
\hline LMG 1044 & 4.7 & - & 2.8 & 1.2 & 21.9 & 2.8 & 1.4 & 61.5 & 3.5 \\
\hline CCUG $63^{c}$ & 5.1 & - & 2.6 & 1.3 & 38.9 & 3.6 & 1.1 & 43.7 & 1.3 \\
\hline CCUG $350^{\mathrm{T}}$ & 5.6 & - & 3.0 & 1.3 & 16.7 & 4.3 & 0.8 & 62.3 & 6.0 \\
\hline CCUG 11977 & 4.1 & - & 2.5 & 1.0 & 15.4 & 2.1 & 1.3 & 70.2 & 3.6 \\
\hline CCUG 13305 & 5.3 & - & 3.1 & - & 17.0 & - & - & 72.9 & 1.7 \\
\hline CCUG 13369 & 6.2 & - & 3.8 & 1.7 & 22.7 & 1.5 & 1.8 & 61.1 & 1.1 \\
\hline CCUG 13705 & 7.2 & - & 4.0 & 1.9 & 20.0 & 2.5 & 2.0 & 59.7 & 2.8 \\
\hline
\end{tabular}

${ }^{a} \mathrm{~B}$, position of the double bound has not been determined.

${ }^{b}$-, Absent or present in trace amounts (less than $1 \%$ ).

${ }^{c}$ An unidentified fatty acid methyl ester with an equivalent chain length of 17.825 was also detected at a level of $2.5 \%$.

Species belonging to the $M$. lacunata rRNA homology group (M. lacunata, $M$. nonliquefaciens, $M$. bovis, $M$. catarrhalis, M. ovis, M. caviae, M. cuniculi, and Moraxella canis) exhibit $T_{m(e)}$ values between 80 and $75.4^{\circ} \mathrm{C}$ with $M$. lacunata rRNA $(9,18)$, while $T_{m(e)}$ values of 74.8 and $74.4^{\circ} \mathrm{C}$ with the same rRNA were measured for two strains belonging to the new taxon (CCUG 24769 and CCUG 9511). Mainly on the basis of analogous $T_{m(e)}$ values we proposed previously that $M$. osloensis should be placed in a separate taxon since we restricted the genus Moraxella to members of the $M$. lacunata subgroup (18). Although differences in $T_{m(e)}$ of $5^{\circ} \mathrm{C}$ are commonly found within genera $(8,12,16,21,24)$, we made this decision mainly because there was a clear difference between the $T_{m(e)}$ values of $M$. osloensis $\left(75.5\right.$ to $75.7^{\circ} \mathrm{C}$ [18]) and the $T_{m(e)}$ values of members of the $M$. lacunata subgroup (76.3 to $80.0^{\circ} \mathrm{C}$ [18]). Now, we include $M$. osloensis and the new taxon in the genus Moraxella because the $T_{m(e)}$ values of these two groups $\left(75.5\right.$ to $75.7^{\circ} \mathrm{C}[18]$ and 74.4 to $74.8^{\circ} \mathrm{C}$, respectively) and the $T_{m(e)}$ values of the other Moraxella species $\left(75.4\right.$ to $\left.80.0^{\circ} \mathrm{C}[9,18]\right)$ overlap when the experimental deviation of $0.5^{\circ} \mathrm{C}$ is taken into account. Whether organisms exhibiting differences in $T_{m(e)}$ values of about $5^{\circ} \mathrm{C}$ should be included in a single genus depends on additional phenotypic and chemotaxonomic parameters. For $M$. osloensis, the phenotypic and chemotaxonomic similarities with all other Moraxella species, including $M$. canis (9), are more decisive than the few distinct features mentioned previously $(2,10,11,17,18)$. This is because the latter were based on a comparison of $M$. osloensis with only one or a few other Moraxella species. Furthermore, the general phenotypic profiles of $M$. osloensis and the new taxon for which we propose the name $M$. lincolnii and the DNA base ratios of these organisms are consistent with the description of the genus Moraxella given in Bergey's Manual of Systematic Bacteriology (1) (Table 2). We therefore conclude that both $M$. lincolnii and $M$. osloensis are genuine members, genotypically as well as phenotypically, of the genus $\mathrm{Mo}$ raxella.

$M$. lincolnii can easily be differentiated from other moraxellas by its lack of growth in the presence of $1.5 \% \mathrm{NaCl}$. Furthermore, the combined results obtained for alkaline phosphatase activity, reduction of nitrate, and growth at $42^{\circ} \mathrm{C}$ (Table 2) also allow differentiation of $M$. lincolnii from all other Moraxella taxa. Additional phenotypic tests useful for the differentiation of Moraxella species are given in Table 2. As shown in Fig. 1, analysis of the cellular protein content also allows clear-cut differentiation between $M$. lincolnii and allied taxa. Although two subgroups could be recognized on the basis of both protein contents and fatty acid contents, the overall profiles revealed that all $10 \mathrm{M}$. lincolnii strains were very similar. Representative strains of the two subgroups exhibited high DNA-DNA binding values (Fig. 1 and Table 2), while the DNA-DNA binding values between $M$. lincolnii strains and representatives of the $M$. lacunata rRNA homology group, including $M$. osloensis, were not significant.

Description of Moraxella lincolnii sp. nov. Moraxella lincolnii (lin' col.ni.i. N. L. gen. n. lincolnii, of Lincoln, in honor of K. Lincoln, a Swedish microbiologist, in recognition of his many contributions in the field of urinary tract infections). Cells are gram-negative, nonmotile, coccus-like to plump rods 1 to $1.5 \mu \mathrm{m}$ wide and 1.5 to $2.5 \mu \mathrm{m}$ long. The cells often occur in pairs and may form short chains. After 2 days of incubation, colonies are whitish, smooth, convex, 
and circular and have a diameter of 1 to $3 \mathrm{~mm}$. The colonies of some strains may have a flattened edge. No hemolysis and no production of pigment or odor. Grows under aerobic, capnophilic, or microaerobic conditions but not anaerobically. Grows on blood agar or nutrient agar, but not on Drigalski agar. Optimal growth occurs at 28 to $33^{\circ} \mathrm{C}$. Growth also occurs at 36 to $37^{\circ} \mathrm{C}$, but not at $42^{\circ} \mathrm{C}$. Growth occurs in the absence of $\mathrm{NaCl}$; no growth occurs in the presence of $1.5 \% \mathrm{NaCl}$. Oxidase and catalase activities are present. All strains are susceptible to penicillin $(10-\mu \mathrm{g}$ discs). Most strains reduce nitrites (seven of nine strains tested). No fermentation or oxidation of D-glucose. No acid production from D-glucose, maltose, D-fructose, or sucrose. Lactate cannot be used as a carbon source. No denitrification, liquefaction of gelatin, proteolysis on Löffler slants, hydrolysis of Tween 80, or indole production. No urease, DNase, or $\beta$-galactosidase activity. Nitrate is not reduced.

Ester lipase $\mathrm{C}_{8}$, esterase, leucine arylamidase, glycine arylamidase, lysine arylamidase, and seryl-methionine arylamidase activities are present; alkaline and acid phosphatase, phosphoamidase, trypsin, chymotrypsin, $\alpha$-galactosidase, $\beta$-glucuronidase, $\alpha$-glucosidase, $\beta$-glucosidase, $N$-acetyl- $\beta$-glucosaminidase, $\alpha$-mannosidase, $\alpha$-fucosidase, lipase $\left(C_{14}\right)$, valine arylamidase, cysteine arylamidase, $\gamma$-glutamyl arylamidase, proline arylamidase, and alanyl-phenylalanyl-prolyl-alanine arylamidase activities are absent.

The DNA base composition of $M$. lincolnii is $44 \mathrm{~mol} \%$ $\mathrm{G}+\mathrm{C}$. The major fatty acids are 10:0, 12:0 30H, 16:1 cis-9, 16:0, 18:1 cis-9, and 18:0.

So far, $M$. lincolnii has been isolated mainly from the respiratory tract of humans. Its clinical significance is unknown.

The type strain is CCUG 9405 (= LMG 5127), which was isolated in 1980 in Göteborg, Sweden, from the nasopharynx of a 5-year-old girl with a fever. All $M$. lincolnii strains have been deposited in the Culture Collection of the University of Göteborg and the Culture Collection of the Laboratorium voor Microbiologie, University of Ghent.

\section{ACKNOWLEDGMENTS}

P.V. is indebted to the National Fund for Scientific Research (Belgium) for a position as a senior research assistant. K.K. and M.G. are indebted to the Fund for Medical Scientific Research, Belgium, for research and personnel grants.

We are indebted to G. Mosella, A. Börjesson, D. Dewettinck, and U. Torck for excellent technical assistance and to D. Monget (API bioMérieux) for providing noncommercial API galleries.

\section{REFERENCES}

1. Bøvre, K. 1984. Genus II. Moraxella Lwoff 1939, 173 emend. Henriksen and Bøvre $1968,391^{\mathrm{AL}}$, p. 296-303. In N. R. Krieg and J. G. Holt (ed.), Bergey's manual of systematic bacteriology, vol. 1. The Williams \& Wilkins Co., Baltimore.

2. Bryn, K., E. Jantzen, and K. Bøvre. 1977. Occurrence and patterns of waxes in Neisseriaceae. J. Gen. Microbiol. 102:3343.

3. De Ley, J. 1970. Reexamination of the association between melting point, buoyant density, and chemical base composition of deoxyribonucleic acid. J. Bacteriol. 101:738-754.

4. De Ley, J., H. Cattoir, and A. Reynaerts. 1970. The quantitative measurement of DNA hybridization from renaturation rates. Eur. J. Biochem. 12:133-142.

5. De Vos, P., K. Kersters, E. Falsen, B. Pot, M. Gillis, P. Segers, and J. De Ley. 1985. Comamonas Davis and Park 1962 gen. nov., nom. rev. emend., and Comamonas terrigena Hugh 1962 sp. nov., nom. rev. Int. J. Syst. Bacteriol. 35:443-453.
6. Falsen, E. 1983. Immunodiffusion as an aid in routine identification of uncommon aerobic Gram negative bacteria, p. 477 483. In H. Leclerc (ed.), Gram negative bacteria of medical and public health importance: taxonomy, identification, applications. Les éditions de l' Institut National de la Santé et de la Recherche Médicale, Paris.

7. Falsen, E. Unpublished data.

8. Gillis, M., K. Kersters, B. Hoste, D. Janssens, R. M. Kroppenstedt, M. P. Stephan, K. R. S. Teixeira, J. Döbereiner, and J. De Ley. 1989. Acetobacter diazotrophicus sp. nov., a nitrogenfixing acetic acid bacterium associated with sugarcane. Int. J. Syst. Bacteriol. 39:361-364.

9. Jannes, G., M. Vaneechoutte, M. Lannoo, M. Gillis, M. Vancanneyt, P. Vandamme, G. Verschraegen, H. Van Heuverswyn, and R. Rossau. 1993. Polyphasic taxonomy leading to the proposal of Moraxella canis sp. nov. for Moraxella catarrhalis-like strains. Int. J. Syst. Bacteriol. 43:438-449.

10. Jantzen, E., K. Bryn, T. Bergan, and K. Bøvre. 1974. Gas chromatography of bacterial whole-cell methanolysates. V. Fatty acid composition of neisseriae and moraxellae. Acta Pathol. Microbiol. Scand. Sect. B 84:9-16.

11. Juni, E. 1974. Simple genetic transformation assay for rapid diagnosis of Moraxella osloensis. Appl. Microbiol. 27:16-24.

12. Kersters, K., and J. De Ley. 1984. Genus Alcaligenes Castellani and Chalmers $1919,936^{\mathrm{AL}}$, p. 361-373. In N. R. Krieg and J. G. Holt (ed.) Bergey's manual of systematic bacteriology, vol. 1. The Williams \& Wilkins Co., Baltimore.

13. Kiredijan, M., B. Holmes, K. Kersters, I. Guilvout, and J. De Ley. 1986. Alcaligenes piechaudii, a new species from human clinical specimens and the environment. Int. J. Syst. Bacteriol. 36:282-287.

14. Marmur, J., and P. Doty. 1962. Determination of the base composition of deoxyribonucleic acid from its thermal denaturation temperature. J. Mol. Biol. 5:109-118.

15. Moss, C. W., P. L. Wallace, D. G. Hollis, and R. E. Weaver. 1988. Cultural and chemical characterization of CDC groups EO-2, M5, and M6, Moraxella (Moraxella) species, Oligella urethralis, Acinetobacter species, and Psychrobacter immobilis. J. Clin. Microbiol. 26:484-492.

16. Reinhold, B., T. Hurek, I. Fendrik, B. Pot, M. Gillis, K. Kersters, S. Thielemans, and J. De Ley. 1987. Azospirillum halopraeferens $\mathrm{sp}$. nov, a nitrogen-fixing organism associated with roots of Kallar grass (Leptochloa fusca (L.) Kunth). Int. J. Syst. Bacteriol. 37:43-51.

17. Rossau, R., K. Kersters, E. Falsen, E. Jantzen, P. Segers, A. Union, L. Nehls, and J. De Ley. 1987. Oligella, a new genus including Oligella urethralis comb. nov. (formerly Moraxella urethralis) and Oligella ureolytica sp. nov. (formerly CDC group IVe): relationship to Taylorella equigenitalis and related taxa. Int. J. Syst. Bacteriol. 37:198-210.

18. Rossau, R., A. Van Landschoot, M. Gillis, and J. De Ley. 1991. Taxonomy of Moraxellaceae fam. nov., a new bacterial family to accomodate the genera Moraxella, Acinetobacter, and Psychrobacter and related organisms. Int. J. Syst. Bacteriol. 41: 310-319.

19. Sugimoto, C., E. Miyagawa, M. Nakazawa, K. Mitani, and Y. Isayama. 1983. Cellular fatty acid composition comparisons of Haemophilus equigenitalis and Moraxella species. Int. J. Syst. Bacteriol. 33:181-187.

20. Vandamme, P., E. Falsen, B. Pot, B. Hoste, K. Kersters, and J. De Ley. 1989. Identification of EF group 22 campylobacters from gastroenteritis cases as Campylobacter concisus. J. Clin. Microbiol, 27:1775-1781.

21. Vandamme, P., E. Falsen, R. Rossau, B. Hoste, P. Segers, R. Tytgat, and J. De Ley. 1991. Revision of Campylobacter, Helicobacter, and Wolinella taxonomy: emendation of generic descriptions and proposal of Arcobacter gen. nov. Int. J. Syst. Bacteriol. 41:88-103.

22. Vandamme, P., M. Vancanneyt, B. Pot, L. Mels, B. Hoste, D. Dewettinck, L. Vlaes, C. Van Den Borre, R. Higgins, J. Hommez, K. Kersters, J.-P. Butzler, and H. Goossens. 1992. Polyphasic taxonomic study of the emended genus Arcobacter with Arco- 
bacter butzleri comb. nov. and Arcobacter skirrowii sp. nov., an aerotolerant bacterium isolated from veterinary specimens. Int. J. Syst. Bacteriol. 42:344-356.

23. Van Landschoot, A., and J. De Ley. 1983. Intra- and intergeneric similarities of the rRNA cistrons of Alteromonas, Marinomonas (gen. nov.) and some other Gram-negative bacteria. J. Gen.
Microbiol. 129:3057-3074.

24. Willems, A., B. Pot, E. Falsen, P. Vandamme, M. Gillis, K. Kersters, and J. De Ley. 1991. Polyphasic taxonomic study of the emended genus Comamonas: relationship to Aquaspirillum aquaticum, E. Falsen group 10, and other clinical isolates. Int. J. Syst. Bacteriol. 41:427-444. 